\title{
Relevance of glomerular C4d deposition in pediatric patients with Henoch-Schönlein Purpura compared to IgA nephritis
}

Research article

Keywords:

Posted Date: December 11th, 2020

DOl: https://doi.org/10.21203/rs.3.rs-52609/v2

License: (c) (1) This work is licensed under a Creative Commons Attribution 4.0 International License.

Read Full License 


\section{Abstract}

The authors have requested that this preprint be withdrawn due to erroneous posting.

\section{Full Text}

The authors have withdrawn this preprint from Research Square. 